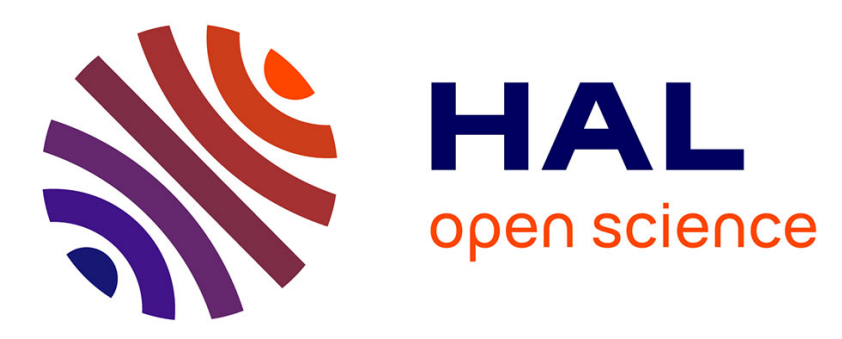

\title{
Identity, virulence genes, and clonal relatedness of isolates from patients with diarrhea and drinking water
} M. Pablos, M.-A. Remacha, J.-M. Rodríguez-Calleja, J. A. Santos, A. Otero, M.-L. García-López

\section{- To cite this version:}

M. Pablos, M.-A. Remacha, J.-M. Rodríguez-Calleja, J. A. Santos, A. Otero, et al.. Identity, virulence genes, and clonal relatedness of isolates from patients with diarrhea and drinking water. European Journal of Clinical Microbiology and Infectious Diseases, 2010, 29 (9), pp.1163-1172. 10.1007/s10096010-0982-3 . hal-00600040

\section{HAL Id: hal-00600040 \\ https://hal.science/hal-00600040}

Submitted on 13 Jun 2011

HAL is a multi-disciplinary open access archive for the deposit and dissemination of scientific research documents, whether they are published or not. The documents may come from teaching and research institutions in France or abroad, or from public or private research centers.
L'archive ouverte pluridisciplinaire HAL, est destinée au dépôt et à la diffusion de documents scientifiques de niveau recherche, publiés ou non, émanant des établissements d'enseignement et de recherche français ou étrangers, des laboratoires publics ou privés. 
Diseases

Editorial Manager(tm) for European Journal of Clinical Microbiology \& Infectious

Manuscript Draft

Manuscript Number: EJCMID-D-09-00648R1

Title: IDENTITY, VIRULENCE GENES AND CLONAL RELATEDNESS OF Aeromonas ISOLATES FROM PATIENTS WITH DIARRHEA AND DRINKING WATER

Article Type: Article

Keywords: Aeromonas; stool specimens; drinking water; PFGE

Corresponding Author: Dr. María-Luisa García-López, Ph.D.

Corresponding Author's Institution: University of León

First Author: Manuel Pablos, M.D.

Order of Authors: Manuel Pablos, M.D.; María-Antonia Remacha, M.D.; Jose M. Rodríguez-Calleja, Ph.D.; Jesús A. Santos, Ph.D.; Andrés Otero, Ph.D.; María-Luisa García-López, Ph.D.

Abstract: Among 800 stool specimens from patients with diarrhea submitted by Primary Care Centers for routine analysis to the Hospital of León (NW Spain) Microbiology and Parasitology Service, 32 (4\%) were tested positive for Aeromonas spp. Mixed infections with other enteric pathogens occurred in 12 patients. A. caviae was isolated from 23 clinical specimens. There also were patients infected with A. media, A. hydrophila, A. bestiarum and A. veronii biovar veronii. All but three isolates carried one or more of the virulence genes. The incidence of the alt, hlyA, aerA, ast and laf genes was 71.9, 28.1, 25.0, 18.8 , and $9.4 \%$, respectively. The alt+/ast+ combination was detected in four isolates and the aerA+/hlyA+ combination in the two A. hydrophila isolates. None of the strains harbored the TTSS, stx 1 or stx 2 genes and nine bore plasmids. Thirty clinical isolates and a collection of $12 \mathrm{~A}$. caviae and A. media strains obtained from León municipal drinking water over the study period were typed by PFGE. PFGE patterns revealed genetic relatedness and persistence over time among water isolates and some clinical isolates. Interestingly, one A. caviae (aerA-/hlyA-/alt+/ast-/laf+) human isolate and two A. caviae (aerA-/hlyA-/alt+/ast-/laf+) drinking water isolates had indistinguishable PFGE patterns, suggesting waterborne infection.

Response to Reviewers: Answers to reviewer's comments:

* Information on the detection of TTSS gene has been included and has been taken into consideration in the "Discussion" section.

* Mistakes have been corrected and some of the suggestions of the reviewer have been included in the manuscript". 
4 Manuel Pablos ${ }^{1}$, María-Antonia Remacha ${ }^{2}$, Jose-María Rodríguez-Calleja ${ }^{1}$, Jesús

7 University of León, 24071-León (Spain) ${ }^{1}$; and Microbiology and Parasitology Service,

8 Hospital of León, 24701-León, (Spain) ${ }^{2}$

$9 \quad{ }^{*}$ Corresponding author:

IDENTITY, VIRULENCE GENES AND CLONAL RELATEDNESS OF A. Santos ${ }^{1}$, Andrés Otero ${ }^{1}$, and María-Luisa García-López ${ }^{1 *}$ Department of Food Hygiene and Food Technology, Veterinary Faculty, Professor María-Luisa García-López

Departamento de Higiene y Tecnología de los Alimentos Facultad de Veterinaria, Universidad de León E-24071-León

Phone: +34987291119

Fax: +34987291284

E-mail: $\underline{\text { mlgarl@unileon.es }}$ 


\section{Abstract}

Among 800 stool specimens from patients with diarrhea submitted by Primary

19 Care Centers for routine analysis to the Hospital of León (NW Spain) Microbiology and 20 Parasitology Service, 32 (4\%) were tested positive for Aeromonas spp. Mixed infections

21 with other enteric pathogens occurred in 12 patients. A. caviae was isolated from 23 22 patientsclinical specimens. There also were patients infected with A. media, A. 23 hydrophila, A. bestiarum and A. veronii biovar veronii. All but three isolates carried one

24 or more of the virulence genes-tested. The incidence of the alt, hlyA, aerA, ast and laf 25 genes was 71.9, 28.1, 25.0, 18.8, and 9.4\%, respectively. The alt $^{+} / a s t^{+}$combination was 26 detected in four isolates and the aer $\mathrm{A}^{+} / h l y \mathrm{~A}^{+}$combination in the two A. hydrophila

27 isolates. None of the strains harbored the E. coli genes-TTSS, stx 1 andor stx 2 genes and 28 nine bore plasmids. Thirty clinical isolates and a collection of 12 A. caviae and A. media 29 strains obtained from León municipal drinking water over the study period were 30 subtyped by PFGE. PFGE patterns revealed genetic relatedness and persistence over 31 time among water isolates and some clinical isolates. Interestingly, one A. caviae (aerA

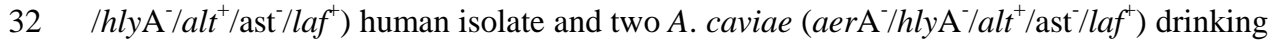
33 water isolates had indistinguishable PFGE patterns, suggesting waterborne infection.

34 Keywords: Aeromonas, stool specimens, drinking water, PFGE 


\section{Introduction}

Aeromonas spp. are primarily aquatic organisms that may be readily isolated

37 from aquatic environments, drinking water and a wide range of foods. Some species

38 cause disease in fish, amphibians and reptiles. In humans, mesophilic Aeromonas are

39 recognized as causative agents of extraintestinal diseases such as septicemia

40 particularly in immunocompromised hosts, wound infections and a number of less well

41 described diseases [26]. Over the past 25 years, mesophilic Aeromonas have received

42 increasing attention as an emergent agent of food borne illness. In Spain, data from the

43 National Epidemiology Centre [16] indicate that Aeromonas spp. occupied the fourth

44 place among causes of total gastrointestinal diseases reported each year over the period

451997 to 2006. Because Aeromonas spp. can occur in municipal drinking water supplies

46 despite water treatment strategies, the possibility of waterborne Aeromonas infections in

47 humans has been discussed [27, 55]. For this reason, some countries such as the

48 Netherlands have set standards for Aeromonas spp. in drinking water [4].

49 Pathogenesis of Aeromonas spp. involves a wide group of virulence

50 determinants, their roles not being conclusively established for any human infections.

51 As for other bacteria, it appears that only certain intraspecific subsets of strains act as

52 human pathogens $[27,51]$. The literature shows that the occurrence of genes encoding

53 hemolytic, cytotoxic, cytotonic and enterotoxic activities (aerA, hlyA, alt, and ast) may

54 contribute to diarrheal-related virulence [24, 41, 54] and that expression of peritrichous

55 flagella encoded by the laf gene cluster enhance eukaryotic cells adherence and

56 invasiveness, and also the ability to form biofilms in vitro [20]. Moreover, the presence

Field Code Changed

Field Code Changed

\section{Field Code Changed}

Field Code Changed

Field Code Changed

Field Code Changed

Field Code Changed 
59 addition, evidence of plasmid encoded expression by Aeromonas isolates of cytotoxins

60 similar to Shiga-like toxins of verotoxigenic E. coli has been observed [23, 44].

61 This study was designed with two aims. The first was to determine the

62 prevalence and the identification of identity of-Aeromonas species in cases of 63 gastroenteritis in a Spanish city (León, NW of the country) and to investigate the

64 presence of virulence-associated genes in isolates from patients with diarrhea. The

65 second aim was to establish the genetic relationships of strains from stool specimens

66 and from León drinking water by using pulsed-field gel electrophoresis (PFGE).

\section{Materials And Methods}

68 Fecal specimens. From October 2005 to January 2007, 800 stool specimens

69 submitted by Primary Care Centers to the Hospital of León Microbiology and

70 Parasitology Service (coverage population, 351.086 inhabitants) were routinely tested

71 for the detection of enteric pathogens (bacteria, enteric viruses and parasites) and also

72 plated on freshly prepared m-Aeromonas selective agar (Merck, KGaA, Darmstadt,

73 Germany). After incubation at $28{ }^{\circ} \mathrm{C}$ for $22 \mathrm{~h}$, a total of 160 suspect colonies were

74 screened for standard phenotypic traits: Gram stain, motility, oxidase and catalase

75 production, fermentation of glucose and resistance to vibriostatic agent O/129 [29].

76 Drinking water isolates. For comparative typing by using pulse field gel

77 electrophoresis (PFGE), we included 12 A. caviae and A. media strains (Table 3) which

78 were isolated during the study period from León municipal drinking water meeting

79 quality standards for indicator organisms and chlorine levels [5].

Phenotypic characterization of Aeromonas isolates from patients with

81 diarrhea. A total of 32 Aeromonas isolates (one from each positive sample) was tested

82 for indole production, gas from glucose, Voges Proskauer, L-arginine hydrolysis, lysine 
83 and ornithine decarboxylase, esculin hydrolysis, susceptibility to $30 \mu \mathrm{g}$ of cephalotin,

84 methyl red test, acid production from m-inositol, L-arabinose, lactose, D-mannitol, 85 salicin, D-sucrose, D-rhamnose, and D-sorbitol, gelatinase and elastase activities, and $\beta$ -

86 hemolysis on sheep blood agar plates as described elsewhere [21]. The phenotypic

87 scheme of Abbott et al. [1] was employed for identification of isolates to Aeromonas

88 Groups level. Additional tests useful in differentiating species within the A. hydrophila

89 complex (A. hydrophila, A. bestiarum and A. salmonicida), the A. caviae complex (A.

90 caviae, A. media and A. eucrenophila), and the Group 1 "ODC (ornithine

91 decarboxylase) + only" (A. veronii biovar veronii and A. allosaccharophila) were also

92 performed [1]. The suicide phenomenon at 30 and $37{ }^{\circ} \mathrm{C}$ was investigated as described

93 by Namdari and Cabelli [33].

94 Detection of associated virulence genes. The target genes investigated in this

95 study, the sequence of each primer, the annealing temperatures, the expected PCR

96 products and their references are listed in Table 1.

97 Genomic DNA was extracted from exponential cultures of the organisms in

98 Trypticase soy broth (Becton Dickinson S.A., Madrid, Spain) taking into account ISO

9922174 general requirements and according to ISO 20837 [6, 7]. PCR amplification and

100 detection of PCR products were performed according to the general requirements

101 described in ISO 22174 and ISO 20838 [6, 8]. PCR conditions for the aerA, hlyA, alt,

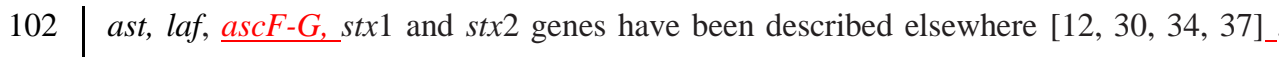

103 Aliquots from each reaction were analyzed by $2 \%$ agarose gel electrophoresis and

104 viewed after ethidium bromide staining under UV light.

105 Plasmids detection. Plasmid DNA isolation was performed with the Quantum

106 Prep Plasmid Miniprep kit (Bio-Rad Laboratories, Hercules, CA) according to the 
107 manufacturer's instructions and analyzed by agarose gel electrophoresis (1.5\%) at $100 \mathrm{~V}$ 108 for $40 \mathrm{~min}$.

109 PFGE. The standardized PulseNet PFGE protocol for pathogenic Gram-negative 110 enteric bacteria [36] and a CHEF-DR III apparatus (Bio-Rad) were used for PFGE 111 analysis. DNA plugs were digested with XbaI restriction enzyme (New England 112 Biolabs, Ipswich, MA, USA). Strains were typed at least at two separate occasions. 113 After electrophoresis, the gels were stained with ethidium bromide, and documented 114 with the Kodak Electrophoresis Documentation and Analysis System 290 (EDAS 290, 115 Kodak Co., Rochester, NY). The banding patterns were analyzed with the GelCompar II 116 program (version 5.1., Applied Maths, St.-Martens-Latem, Belgium). Similarity 117 between fingerprints was calculated with the Dice coefficient. Cluster analysis was 118 performed using the unweighted pair-group method with average linkages (UPGMA).

119 Isolates were considered genetically "indistinguishable" if their PFGE patterns were $120100 \%$ similar and "closely related" if they showed more than $85 \%$ similarity, 121 corresponding to one to three band differences [48]. Isolates with PFGE profiles 122 showing less than $85 \%$ similarity were defined as being genetically unrelated strains. A 123 similarity threshold of $>85 \%$ defined clusters.

\section{Results}

125 Of the 800 stool samples evaluated, 32 samples from different patients were 126 positive for Aeromonas spp. with an overall positivity rate of 4\%. There were 17 127 positive samples when the mean monthly environmental temperature was below $12{ }^{\circ} \mathrm{C}$ 128 and 15 when the mean monthly environmental temperature ranged between 12 and 24.3

$129{ }^{\circ} \mathrm{C}$ (http://clima.meteored.com/clima-en-Europa.html).

130 Information about patients and Aeromonas isolates recovered from their stools is 131 shown in Table 2. All positive samples except one were from outpatients. Of the 32 
132 selected Aeromonas isolates (one from each patient), 26 were allocated to the A. caviae

133 complex, four to the A. hydrophila complex and two to the "ODC+ only" Group 1.

134 The species found were A. caviae (23 patients, 71.9\%), A. media ( 3 patients, 9.4\%), A.

135 hydrophila (2 patients, 6.2\%), A. bestiarum (2 patients, 6.2\%), and A. veronii biovar

136 veronii (2 patients, 6.2\%). Mixed infections occurred in 12 patients (37.5\%), and other

137 pathogens that were found concurrently with $A$. caviae or A. media included

138 Campylobacter (6 patients, 18.7\%), Salmonella (4 patients, 12.5\%) and Giardia lamblia

139 (1 patient, 3.1\%). Ascaris lumbricoides was present with A. media and Campylobacter

140 in one patient $(3.1 \%)$. One further patient was a 3 years old boy with GHD (growth

141 hormone deficiency).

142 Information from questionnaires completed by physicians reported that 27 143 patients had acute diarrhea without vomiting, two had chronic diarrhea, and three had

144 diarrhea, vomits and fever. Stool samples from pediatric patients (up to 14 years old)

145 and males accounted for $68.7 \%$ and $56.2 \%$ of the Aeromonas isolates, respectively. The

14627 patients with acute diarrhea were infected with strains of the five Aeromonas species

147 found, 12 of them being simultaneously positive for other enteric pathogens (Table 2).

148 Patients with chronic diarrhea and those with diarrhea, vomits and fever were infected

149 with A. caviae alone and one with A. hydrophila alone.

150 The distribution of associated virulence genes among the Aeromonas diarrheal

151 isolates is summarized in Table 3. None of the strains harbored the genes $\operatorname{ascF-G,stx1}$ 152 or stx 2 and nine bore plasmids. $\beta$-hemolysis on sheep blood agar plates was only 153 displayed by isolates carrying the aerA and/or the hlyA genes, the remaining isolates 154 showing zones of incomplete hemolysis.

155 Two human isolates (H8 and H9) were consistently non-typeable with the PFGE 156 applied method neither by using a second enzyme (SpeI). PFGE following XbaI 
157 digestion identified 30 patterns whose profiles differed by at least one band. The 158 dendrogram obtained (Fig. 1) showed a cluster (cluster B) of eight A. media water 159 strains with $100 \%$ similarity. The remaining water isolates (A. caviae) grouped together 160 in cluster G, two of them (W73 and W74) being indistinguishable from strain H13 161 recovered from a 51 years old female, without apparent underlying medical 162 complications, who was negative for other enteric pathogens. There were two clusters 163 with two human isolates with identical $\mathrm{XbaI}$ PFGE profiles: two identified as $A$. 164 bestiarum (cluster A) and two as A. caviae (cluster F). Other clusters (C, D, E and H) 165 included nine closely related A. caviae isolates from patients with diarrhea. 166 Indistinguishable isolates possessed identical virulence genes.

\section{Discussion}

168 One of the most commonly reported human infections by Aeromonas spp. is 169 gastroenteritis. Clinical manifestations of disease can range from mild self-limiting 170 watery diarrhea to a more severe and invasive dysenteric form. Chronic diarrheal 171 episodes and isolated cases of a cholera-like illness have also been described [26]. In 172 several reported studies throughout the world, Aeromonas spp. have been isolated at a 173 rate of 0.6 to $7.2 \%$ from patients with diarrhea predominantly from infants and children

$174[3,10,18,31,43,53]$. The highest rate, 52.4\%, was detected in Peruvian infants with 175 severe diarrhea although $57.6 \%$ of the Aeromonas-positive patients had mixed 176 infections with other enteric pathogens [35]. A similar high frequency of co infection 177 has been found in Bangladesh and India [3, 43]. Our results are in agreement with those 178 found in most of the above surveys. Thus, Aeromonas spp. was isolated from $4.0 \%$ of 179 the patients, most of them being infants $(46.9 \%)$ and other pediatric patients $(21.9 \%)$. 180 Clinically, acute illness was the most common symptom whereas fever, vomiting or 
181 chronic diarrhea were present in only a few cases. In addition, common enteric

182 pathogens other than Aeromonas spp. were recovered from more than one third of 183 diarrheic stools. Because of the ubiquitous nature of Aeromonas spp. in raw foods and

184 water, it has been argued that in mixed infections these bacteria are transient colonizer

185 without causal relationship with disease, but also that multiple pathogens may act

186 synergistically to produce diarrhea [3, 35]. Unlike most surveys that have found peaks

187 of Aeromonas-associated gastroenteritis in warmer months, we did not observe seasonal 188 patterns for isolation.

189 The majority of our isolates (71.9\%), which were identified to phenospecies with

190 biochemical schemes [1] and later confirmed by molecular methods (AFLP and gyrB

191 gene sequences; data not shown), belonged to the species A. caviae. There also were

192 some isolates of A. media, A. hydrophila, A. bestiarum and A. veronii biovar veronii. In

193 several studies conducted in Europe, the United States and India, A. caviae was 194 dominant followed by A. hydrophila and A. veronii biovar sobria [3, 10, 18, 31, 43, 53].

195 This agrees with an earlier report from Spain [49], which noted that, between 1989 and

196 1999, the three species accounted for 90\% of all Aeromonas-associated gastroenteritis.

197 Other studies in Brazil, Thailand and India [28, 51] reported A. hydrophila as 198 predominant, and a high isolation rate of $A$. trota has also been found [3]. These

199 differences may depend on the geographical location but also on other factors at least in 200 part related to the isolation and identification methods used. Thus, as most Aeromonas 201 culture media contain ampicillin, the high incidence of A. trota, an ampicillin202 susceptible species, found by the latter authors was attributed to the isolation technique 203 used.

A. media is isolated from the environment and occasionally from patients with 205 diarrhea [3], but its clinical significance is not known [29] although Singh [42] reported 
206 that regardless of their source, A. media strains are potentially enterotoxigenic. In this

207 study, two of the A. media positive patients had concurrent infection with Salmonella.

208 A. veronii biovar veronii and A. bestiarum have rarely been isolated from humans and

209 little information is available regarding its occurrence in clinical specimens; however,

210 two strains of each species were isolated by us as the sole pathogen from two children

211 and two elderly men, and also from gastroenteritis in Switzerland, India and Brazil [14,

$21225,43]$.

213 The pathogenicity of Aeromonas spp. is multifactorial and complex and may

214 involve the products of a number of different genes acting either alone or in concert [19,

215 40]. One rational approach to determine whether Aeromonas strains have the potential

216 to be virulent is to screening for an array of virulence-related genes [2, 52]. A potent

217 virulence factor of Aeromonas strains is the cytotoxic enterotoxin Act, which is closely 218 related to aerolysin (AerA), both of them being hemolytic, cytotoxic, enterotoxic and

219 lethal for mice. Aeromonas may also produce heat labile (Alt) and heat stable (Ast)

220 cytotonic enterotoxins [19]. Sha et al. [41] established a role for the three enterotoxins

221 in causing gastroenteritis in a mouse model by developing isogenic mutants with the 222 major contribution from Act, followed by the Alt and Ast. Results from Albert et al. [3] 223 suggest that the product of both the alt and ast genes may act synergistically to induce 224 severe diarrhea.

225 The incidence of the aerA, alt and ast genes in our clinical isolates was $25,71.9$ 226 and $18.8 \%$, respectively, the alt $^{+} / \mathrm{ast}^{+}$combination being detected in four of them 227 (12.5\%). These findings are comparable with those of Sinha et al. [43] who, in isolates 228 from Indian patients with acute diarrhea, found that act/aerA accounted for $30 \%$, alt 229 was dominant and ast was the less prevalent. Overall, among fecal isolates from Mexico 230 and Catalonia (Spain), Aguilera-Arreola et al. [2] reported that genes for the aerolysin- 
231 hemolysin, Alt, Ast and Alt + Ast toxins accounted for $89.0 \%, 34.9 \%, 28.4 \%$ and $7.3 \%$,

232 respectively. Among their A. caviae isolates, 90.2\% carried the genes encoding cytolytic

233 activity whereas the alt gene was present in only $9.8 \%$. By contrast, we have detected in

234 A. caviae an occurrence of the aerA and alt genes of 21.7 and $73.9 \%$, respectively. A

235 survey in Bangladesh [3] found absence of the act gene alone and a high incidence of

236 the alt and alt $^{+} /$ast $^{+}$genes in isolates from children with diarrhea.

237 In addition to the enterotoxic Act/aerA, which causes $\beta$-hemolysis, a $\beta$ -

238 hemolytic Vibrio cholerae-like hemolysin (HlyA) has been described. The aer $\mathrm{A}^{+} / h \mathrm{~A}^{+}$

239 genotype and in some cases the aer $\mathrm{A}^{+} / h l y \mathrm{~A}^{-}$genotype have been reported to be

240 reasonable predictors of human diarrheal disease [24]. Combination of both genes,

241 which are less common in A. caviae than in A. hydrophila, was only present in the two

242 A. hydrophila isolates. In an earlier study [22], we found that strains belonging to the

243 genotypes $\operatorname{aer} \mathrm{A}^{+} / h l y \mathrm{~A}^{+}, \operatorname{aer} \mathrm{A}^{+} / h l y \mathrm{~A}^{-}$and $\operatorname{aer} \mathrm{A}^{-} / h l y \mathrm{~A}^{-}$were enterotoxic in the suckling

244 mouse test and had the capability to express other virulence traits (proteolytic,

245 hemolytic and cytotoxic activities) at different temperatures.

246 Swarming motility, a lateral flagella dependent behavior, has been implicated in

247 biofilms formation and adhesion to eukaryotic cells. The gene cluster laf responsible for

248 Aeromonas lateral flagella production [20] was detected in three human isolates $(9.4 \%)$

249 which is lower than the incidence (36.7\%) found by Aguilera-Arriola et al. [2].

250 However, all of our drinking water isolates carried the laf gene, two of them (W73 and

251 W74) being, by PFGE, indistinguishable from the human isolate H13 (Fig 1).

252 In this study, there were three A. caviae strains that did not amplify any of the

253 genes tested although they showed incomplete hemolysis and two were recovered as the

254 only suspect pathogen. Negative PCR results do not exclude pathogenicity because at

255 least some Aeromonas strains possess a wide range of virulence factors, other than those 
256 tested by us, that enable them to overcome host defenses and establish infection. Among

257 these factors are surface molecules, different toxins, many enzymes, iron acquisition

258 systems, protein secretion systems and novel virulence determinants that may play an

259 important role in pathogenesis $[19,39,40]$.

260 Our results and those from others suggest that in Aeromonas clinical isolates the 261 distribution pattern of associated-virulence genes varies depending on the species and 262 geographical location and also that despite current knowledge of Aeromonas virulence 263 determinants, there is still no way to identify a given clinical or environmental isolate 264 that has the capacity to cause human illness although some data indicate a role of both 265 the bacterial virulence factors and host-responses [19]. 277 stx 2 genes and plasmids. None of our isolates were PCR positive for the stx genes and $27828 \%$ harbored plasmids. Although most strains of $A$. salmonicida carry at least one large 279 plasmid, plasmids are detected less commonly (15 to 30\%) in human diarrhea280 associated Aeromonas isolates [11]. 
PFGE, which has remarkable discriminatory power and reproducibility, has been

282 successfully applied to the subtyping of many pathogenic bacteria [9]. Over the last 283 years, a number of studies using PFGE and other molecular methods have been used for comparative typing of clinical and/or environmental Aeromonas strains [10, 15, 32, 4547] most of them concluding: (i) that specific clones colonized certain aquatic ecosystems such as drinking water supplies probably as consequence of biofilms development, (ii) that there was not similarity among clinical isolates, and (iii) that stools and drinking water isolates were genetically unrelated. In one of the earliest studies, following a number of cases of diarrhea in children using a small community

290 water supply, Moyer et al. [32] reported colonization of the water supply with Aeromonas identical ribotypes, but unique ribotypes in Aeromonas patient strains, concluding that water was not the source of Aeromonas infections. Similar results were obtained in French studies using RAPD and PFGE for typing isolates from hospitalacquired infections and from the hospital water supply [46, 47]. De la Morena et al. [15] studied Aeromonas isolates recovered from children involved in two outbreaks of gastroenteritis in day-care centers, finding that the PFGE patterns differed in all except 297 two strains. Also by PFGE, Aeromonas isolates from patients with diarrhea and 298 groundwater isolates from private wells throughout Wisconsin were genetically 299 unrelated [10]. By using RAPD, REP-PCR and ERIC-PCR, Szczuka and Kaznowski 300 [45] found that strains isolated from patients in Poland, different parts of Europe and 301 Asia were different clones and that there was not genetic similarity between clinical and 302 environmental strains although the persistence of a single clone in a city water 303 distribution was observed.

In this study, PFGE analysis of the water isolates revealed persistence of two 305 indistinguishable or closely related (up to three band differences) clones of A. media and 
306 A. caviae in the water distribution system of León over the 16 months study period. For

307 clinical isolates, different PFGE patterns were present in stool specimens, some of them

308 grouping in clusters of indistinguishable or closely related strains. Interestingly, there

309 was no clear relation among the origin of isolates or time of isolation; for instance, the

310 two A. caviae isolates in cluster C were recovered in October 2005 and May 2006, those

311 in cluster D in February and October 2006 and those in cluster E in April 2006 and

312 January 2007. The indistinguishable isolates grouped in clusters A and F were detected

313 in the same months (March and June 2006) but from samples obtained in four different

314 Primary Care Centers. It is also noteworthy that one A. caviae clinical isolate and two $A$.

315 caviae water isolates with identical pattern of associated-virulence genes $\left(a e r \mathrm{~A}^{-} / h l y \mathrm{~A}\right.$

316 /alt $^{+} /$ast $^{-} /$laf $^{+}$) showed identical pulsotype providing a link between Aeromonas spp. and 317 diarrheal disease. Chopra [13] also reported that two pairs of A. caviae/A.media isolates

318 from water and patients carrying only one of the three enterotoxin genes (alt) had

319 indistinguishable PFGE patterns, the author indicating that biochemical identification of

320 isolates, determination of virulence traits and DNA fingerprinting could provide

321 necessary information on the pathogenic potential of Aeromonas spp. that can cause 322 waterborne infections.

323 In summary, infection with Aeromonas spp., mainly A. caviae, occurred 324 throughout the year and was significantly more common in pediatric patients. Acute 325 diarrhea was the predominant clinical feature, with the majority of isolates harboring 326 associated-virulence genes. PFGE of human and water isolates, which were recovered 327 from the same geographic area during the same time period, revealed genetic 328 relatedness and persistence over time in water and some clinical isolates. Interestingly, 329 one human isolate had indistinguishable PFGE pattern and identical virulence pattern 330 than two water isolates, suggesting waterborne infection. 


\section{Acknowledgments}

This work was supported by Spanish CICYT (grant AGL2004-04672-ALI) and

333 Junta de Castilla y León (Ayuda Grupo de Excelencia GR155). Manuel Pablos was 334 beneficiary of a fellowship from MEC.

We thank Borja Linage for help in PFGE testing. We also appreciate the kind 336 collaboration of Dr F. Cachón (Microbiology and Parasitology Service, Hospital of 337 León).

\section{References}

339 1. Abbott SL, Cheung WKW, Janda JM (2003) The genus Aeromonas: 340 biochemical characteristics, atypical reactions, and phenotypic identification 341 schemes. J Clin Microbiol 41(6):2348-2357. doi:10.1128/JCM.41.6.23482357.2003 
5. Anonymous (2003) Real Decreto 140/2003, de 7 de febrero, por el que se establecen los criterios sanitarios de la calidad del agua de consumo humano. Boletín Oficial del Estado B.O.E. 45, 21/02/2003:7228-7245.

6. Anonymous (2005) ISO 22174:2005. Microbiology of food and animal feeding stuffs. Polymerase chain reaction (PCR) for the detection of food-borne pathogens. General requirements and definitions. International Organization for Standardization. Geneva.

7. Anonymous (2006) ISO 20837:2006. Microbiology of food and animal feeding stuffs. Polymerase chain reaction (PCR) for the detection of food-borne pathogens. Requirements for sample preparation for qualitative detection. International Organization for Standardization. Geneva.

8. Anonymous (2006) ISO 20838:2006. Microbiology of food and animal feeding stuffs. Polymerase chain reaction (PCR) for the detection of food-borne pathogens. Requirements for amplification and detection for qualitative methods. International Organization for Standardization. Geneva. 
9. Barrett TJ, Gerner-Smidt P, Swaminathan B (2006) Interpretation of pulsed-field gel electrophoresis patterns in foodborne disease investigations and surveillance. Foodborne Pathog Dis 3(1):20-31. doi:10.1089/fpd.2006.3.20.

10. Borchardt MA, Stemper ME, Standridge JH (2003) Aeromonas isolates from human diarrheic stool and groundwater compared by pulsed-field gel electrophoresis. Emerg Infect Dis 9(2):224-228. Available via CDC: http://www.cdc.gov/ncidod/EID/vol9no2/02-0031.htm. Accessed 8 October 2009

11. Brown RL, Sanderson K, Kirov SM (1997) Plasmids and Aeromonas virulence. FEMS Immunol Med Microbiol 17(4):217-223. doi:10.1111/j.1574 695X.1997.tb01015.x. Formatted: Font: Italic

\section{Formatted: Font: Italic}

Formatted: Font: Italic

388 14. Crivelli C, Demarta A, Peduzzi R (2001) Intestinal secretory immunoglobulin A $389 \quad(\operatorname{sIg} \mathrm{A})$ response to Aeromonas exoproteins in patients with naturally acquired Formatted: Font: Italic Aeromonas diarrhea. FEMS Immunol Med Microbiol 30(1):31-35. Formatted: Font: Italic doi:10.1111/j.1574-695X.2001.tb01546.x. 
15. de la Morena ML, Van R, Singh K, Brian M, Murray ME, Pickering LK (1993) Diarrhea associated with Aeromonas species in children in day care centers. J Infect Dis 168(1):215-218. 402 Aeromonas hemolytic uremic syndrome. A case and a review of the literature. 403 Diagn Microbiol Infect Dis 58(2):231-234. doi:10.1016/j.diagmicrobio.2006.11.023.

18. Figura N, Marri L, Verdiani S, Ceccherini C, Barberi A (1986) Prevalence, species differentiation, and toxigenicity of Aeromonas strains in cases of childhood gastroenteritis and in controls. J Clin Microbiol 23(3):595-599.

19. Galindo CL, Sha J, Fadl AA, Pillai LL, Chopra AK (2006) Host immune responses to Aeromonas virulence factors. Curr Immunol Rev 2(1):13-26.

16. Epidemiological Surveillance System (2007) Epidemiological comment on reported diseases and Microbiological Information System. Year 2006. Spain. Boletín Epidemiológico Semanal. Instituto de Salud Carlos III. MSC vol.15:109-114. Available via ISCIII:

http://www.isciii.es/htdocs/centros/epidemiologia/boletin_semanal/bes0719.pdf. Accessed 8 October 2009.

17. Figueras MJ, Aldea MJ, Fernández N, Aspíroz C, Alperi A, Guarro J (2007) Formatted: Font: Italic

Formatted: Font: Italic 
20. Gavin R, Merino S, Altarriba M, Canals R, Shaw JG, Tomas JM (2003) Lateral flagella are required for increased cell adherence, invasion and biofilm

formation by Aeromonas spp. FEMS Microbiol Lett 224(1):77-83.

Formatted: Font: Italic

22. González-Serrano CJ, Santos JA, García-López ML, Otero A (2002) Virulence markers in Aeromonas hydrophila and Aeromonas veronii biovar sobria isolates from freshwater fish and from a diarrhoea case. J Appl Microbiol 93(3):414-419. doi:10.1046/j.1365-2672.2002.01705.x.

23. Haque QM, Sugiyama A, Iwade Y, Midorikawa Y, Yamauchi T (1996) Diarrheal and environmental isolates of Aeromonas spp. produce a toxin similar

Formatted: Font: Italic
Formatted: Font: Italic
Formatted: Font: Italic

21. González-Rodríguez MN, Sanz JJ, Santos JA, Otero A, García-López ML (2002) Foodborne pathogenic bacteria in prepackaged fresh retail portions of farmed rainbow trout and salmon stored at $3{ }^{\circ} \mathrm{C}$. Int J Food Microbiol 76(12):135-141. doi:10.1016/S0168-1605(02)00011-9.

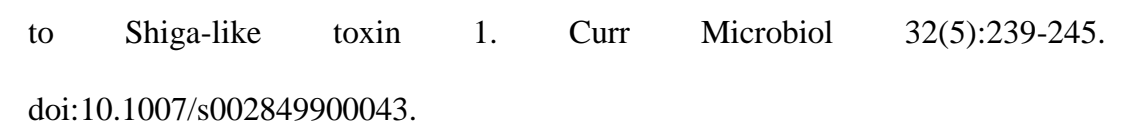

24. Heuzenroeder MW, Wong CYF, Flower RLP (1999) Distribution of two hemolytic toxin genes in clinical and environmental isolates of Aeromonas spp.: correlation with virulence in a suckling mouse model. FEMS Microbiol Lett 174(1):131-136. doi:10.1111/j.1574-6968.1999.tb13559.x. 
25. Hofer E, Reis CM, Theophilo GN, Cavalcanti VO, Lima NV, Henriques MF (2006) Aeromonas associated with an acute diarrhea outbreak in Sao Bento do

\section{Formatted: Font: Italic} Una, Pernambuco. Rev Soc Bras Med Trop 39(2):217-220. doi:10.1590/S003786822006000200016

26. Janda JM, Abbott SL (1998) Evolving concepts regarding the genus Aeromonas: an expanding panorama of species, disease presentations, and unanswered questions. Clin Infect Dis 27(2):332-344. doi:10.1086/514652.

27. Joseph SW, Carnahan AM (2000) Update on the genus Aeromonas. (66):218223. ASM News. Available via ASM News: http://newsarchive.asm.org/apr00/feature3.asp. Accessed 13 October 2009.

28. Kannan S, Chattopadhyay UK, Pal D, Shimada T, Takeda Y, Bhattacharya SK, Ananthanarayanan PH (2001) Isolation and identification of aeromonas from patients with acute diarrhoea in Kolkata, India. Indian $\mathrm{J}$ Med Microbiol 19(4):190-192. Available via IJMM:

http://www.ijmm.org/text.asp?2001/19/4/190/8187. Accessed 13 October 2009.

29. Kirov SM (2001) Aeromonas and Plesiomonas. In Doyle MP, Beuchat LR, Montville TJ (eds.) Food Microbiology: Fundamentals and Frontiers, 2nd . ASM Press, Washington, D.C. pp 301-327. and after depuration. J Food Prot 72(7):1443-1449. 
31. Moyer NP (1987) Clinical significance of Aeromonas species isolated from patients with diarrhea. J Clin Microbiol 25(11):2044-2048.

32. Moyer NP, Luccini GM, Holcomb LA, Hall NH, Altwegg M (1992) Application of ribotyping for differentiating aeromonads isolated from clinical and environmental sources. Appl Environ Microbiol 58(6):1940-1944.

33. Namdari H, Cabelli VJ (1989) The suicide phenomenon in motile aeromonads. Appl Environ Microbiol 55(3):543-547.

34. Paton AW, Paton JC (1998) Detection and characterization of Shiga toxigenic

Escherichia coli by using multiplex PCR assays for st $x_{1}, s t x_{2}$, eaeA, enterohemorrhagic E. coli $h l y A, r f b_{.0111}$, and $r f b_{\mathrm{O} 157}$. J Clin Microbiol 36(2):598602.

35. Pazzaglia G, Sack RB, Salazar E, Yi A, Chea E, Leon-Barua R, Guerrero CE,

Palomino J (1991) High frequency of coinfecting enteropathogens in Aeromonas-associated diarrhea of hospitalized Peruvian infants. J Clin Microbiol 29(6):1151-1156.

466 36. Ribot EM, Fair MA, Gautom R, Cameron DN, Hunter SB, Swaminathan B, 467 Barrett TJ (2006) Standardization of Pulsed-Field Gel Electrophoresis Protocols 468 469

for the subtyping of Escherichia coli O157:H7, Salmonella, and Shigella for PulseNet. Foodborne Pathog Dis 3(1):59-67. doi:10.1089/fpd.2006.3.59.

\begin{tabular}{|l|}
\hline Formatted: Font: Italic \\
\hline Formatted: Font: Italic \\
\hline Formatted: Subscript \\
\hline Formatted: Font: Italic \\
\hline Formatted: Subscript \\
\hline Formatted: Font: Italic \\
\hline Formatted: Font: Italic \\
\hline Formatted: Font: Italic \\
\hline Formatted: Font: Italic \\
\hline Formatted: Subscript \\
\hline Formatted: Font: Italic
\end{tabular}

Formatted: Font: Italic

Formatted: Font: Italic

Formatted: Font: Italic 
37. Rodríguez-Calleja JM, García-López I, García-López ML, Santos JA, Otero A (2006) Rabbit meat as a source of bacterial foodborne pathogens. J Food Prot 69(5):1106-1112

42. Singh DV (2000) A putative heat-labile enterotoxin expressed by strains of Aeromonas media. J Med Microbiol 49(8):685-689.

\section{Formatted: Font: Italic}

Formatted: Font: Italic

41. Sha J, Kozlova EV, Chopra AK (2002) Role of various enterotoxins in Aeromonas hydrophila-induced gastroenteritis: generation of enterotoxin gene-

Formatted: Font: Italic deficient mutants and evaluation of their enterotoxic activity. Infect Immun 70(4):1924-1935. doi:10.1128/IAI.70.4.1924-1935.2002. 
43. Sinha S, Shimada T, Ramamurthy T, Bhattacharya SK, Yamasaki S, Takeda Y, Nair GB (2004) Prevalence, serotype distribution, antibiotic susceptibility and

44. Snowden L, Wernbacher L, Stenzel D, Tucker J, McKay D, O'Brien M, Katouli M (2006) Prevalence of environmental Aeromonas in South East Queensland, Australia: a study of their interactions with human monolayer Caco-2 cells. J Appl Microbiol 101(4):964-975. doi:10.1111/j.1365-2672.2006.02919.x.

45. Szczuka E, Kaznowski A (2004) Typing of clinical and environmental Aeromonas sp. strains by random amplified polymorphic DNA PCR, repetitive extragenic palindromic PCR, and enterobacterial repetitive intergenic consensus sequence PCR. J Clin Microbiol 42(1):220-228. doi:10.1128/JCM.42.1.220228.2004 .

46. Talon D, Dupont MJ, Lesne J, Thouverez M, Michel-Briand Y (1996) Pulsedfield gel electrophoresis as an epidemiological tool for clonal identification of Aeromonas hydrophila. J Appl Bacteriol 80(3):277-282. doi:10.1111/j.13652672.1996.tb03220.x.

47. Talon D, Mulin B, Thouverez M (1998) Clonal identification of Aeromonas Formatted: Font: Italic hydrophila strains using randomly amplified polymorphic DNA analysis. Eur J Epidemiol 14(3):305-310. doi:10.1023/A:1007441019821. 
49. Velasco-Muñoz L, Cano-Portero R, de Mateo-Ontañón S (1999) Aeromonas infection surveillance in Spain. Years 1989-1999. Spain. Boletín Epidemiológico Semanal. Instituto de Salud Carlos III. MSC vol.7:197-208. Available via ISCIII: http://www.isciii.es/htdocs/centros/epidemiologia/boletin_semanal/bes9941.pdf. Accessed 8 October 2009.

50. Vilches S, Urgell C, Merino S, Chacón MR, Soler L, Castro-Escarpulli G, Figueras MJ, Tomás JM (2004) Complete type III secretion system of a mesophilic Aeromonas hydrophila strain. Appl Environ Microbiol 70(11):69146919. 10.1128/AEM.70.11.6914-6919.2004.

51. von Graevenitz A (2007) The role of Aeromonas in diarrhea: a review. Infection Formatted: Font: Italic 35(2):59-64. doi:10.1007/s15010-007-6243-4.

52. Wang G, Clark CG, Liu C, Pucknell C, Munro CK, Kruk TM, Caldeira R, Woodward DL, Rodgers FG (2003) Detection and characterization of the hemolysin genes in Aeromonas hydrophila and Aeromonas sobria by multiplex PCR. J Clin Microbiol 41(3):1048-1054. doi:10.1128/JCM.41.3.1048- 
53. Wilcox MH, Cook AM, Eley A, Spencer RC (1992) Aeromonas spp. as a Formatted: Font: Italic potential cause of diarrhoea in children. J Clin Pathol 45(11):959-963.

535 54. Wong CY, Heuzenroeder MW, Flower RL (1998) Inactivation of two 536 haemolytic toxin genes in Aeromonas hydrophila attenuates virulence in a 537 suckling mouse model. Microbiology 144:291-298. doi:10.1099/00221287-144$2-291$.

55. World Health Organization-WHO (2002) Guidelines for drinking-water quality. Addendum: microbiological agents in drinking water. Available via WHO: www.who.int/water_sanitation_health/dwq/gdwq2v1/en/print.html. Accessed 8 October 2009.

56. Yu HB, Rao PS, Lee HC, Vilches S, Merino S, Tomas JM, Leung KY (2004) A type III secretion system is required for Aeromonas hydrophila AH-1 Formatted: Font: Italic pathogenesis. Infect Immun 72(3):1248-1256. doi:10.1128/IAI.72.3.12481256.2004. 
Table 1 PCR primers, annealing temperatures and expected PCR products for

$548 \quad$ virulence associated genes

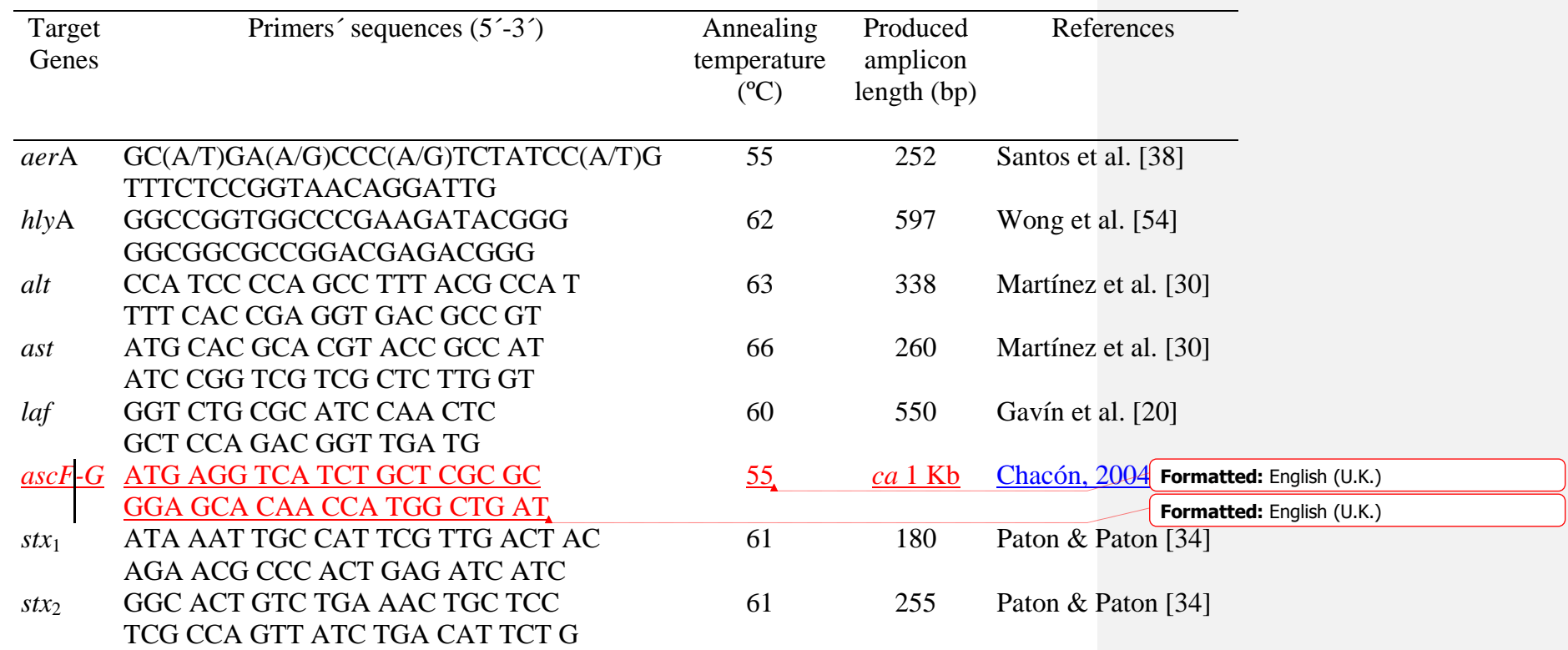


Table 2 Symptoms, age and gender of patients suffering from gastroenteritis associated with Aeromonas spp.

\begin{tabular}{|c|c|c|c|c|c|c|c|c|c|}
\hline \multirow[t]{2}{*}{ Symptoms } & \multicolumn{5}{|c|}{ Age (years) } & \multirow[b]{2}{*}{ Species } & \multirow[b]{2}{*}{$\begin{array}{l}\text { No. of } \\
\text { patients }\end{array}$} & \multirow[b]{2}{*}{ Other organisms } & \multirow[b]{2}{*}{$\begin{array}{l}\text { No. of } \\
\text { patients }\end{array}$} \\
\hline & $\begin{array}{c}\text { Total } \\
\text { patients }\end{array}$ & $\leq 2$ & $>2-14$ & $>14-65$ & $>65$ & & & & \\
\hline Acute diarrhea & 27 & 12 & 6 & 4 & 5 & & & & \\
\hline \multirow[t]{10}{*}{ Gender $(\mathrm{F} / \mathrm{M})^{\mathrm{a}}$} & $(10 / 17)$ & $(5 / 7)$ & $(2 / 4)$ & $(2 / 2)$ & $(1 / 4)$ & & & & \\
\hline & & & & & & A. caviae & 19 & & \\
\hline & & & & & & A. media & 3 & & \\
\hline & & & & & & A. bestiarum & 2 & & \\
\hline & & & & & & A. veronii biovar veronii & 2 & & \\
\hline & & & & & & A. hydrophila & 1 & & \\
\hline & & & & & & & & Campylobacter & 6 \\
\hline & & & & & & & & Salmonella & 4 \\
\hline & & & & & & & & Campylobacter + Ascaris & 1 \\
\hline & & & & & & & & Giardia lamblia & 1 \\
\hline Chronic diarrhea & 2 & 2 & & & & & & & \\
\hline \multirow[t]{2}{*}{ Gender (F/M) } & $(2 / 0)$ & $(2 / 0)$ & & & & & & & \\
\hline & & & & & & A. caviae & 2 & & \\
\hline Vomits/diarrhea/fever & 3 & 1 & 1 & & 1 & & & & \\
\hline \multirow[t]{3}{*}{ Gender $\left(\mathrm{F} / \mathrm{M}^{\mathrm{a}}\right)$} & $(2 / 1)$ & $(0 / 1)$ & $(1 / 0)$ & & $(1 / 0)$ & & & & \\
\hline & & & & & & A. caviae & 2 & & \\
\hline & & & & & & A. hydrophila & 1 & & \\
\hline
\end{tabular}




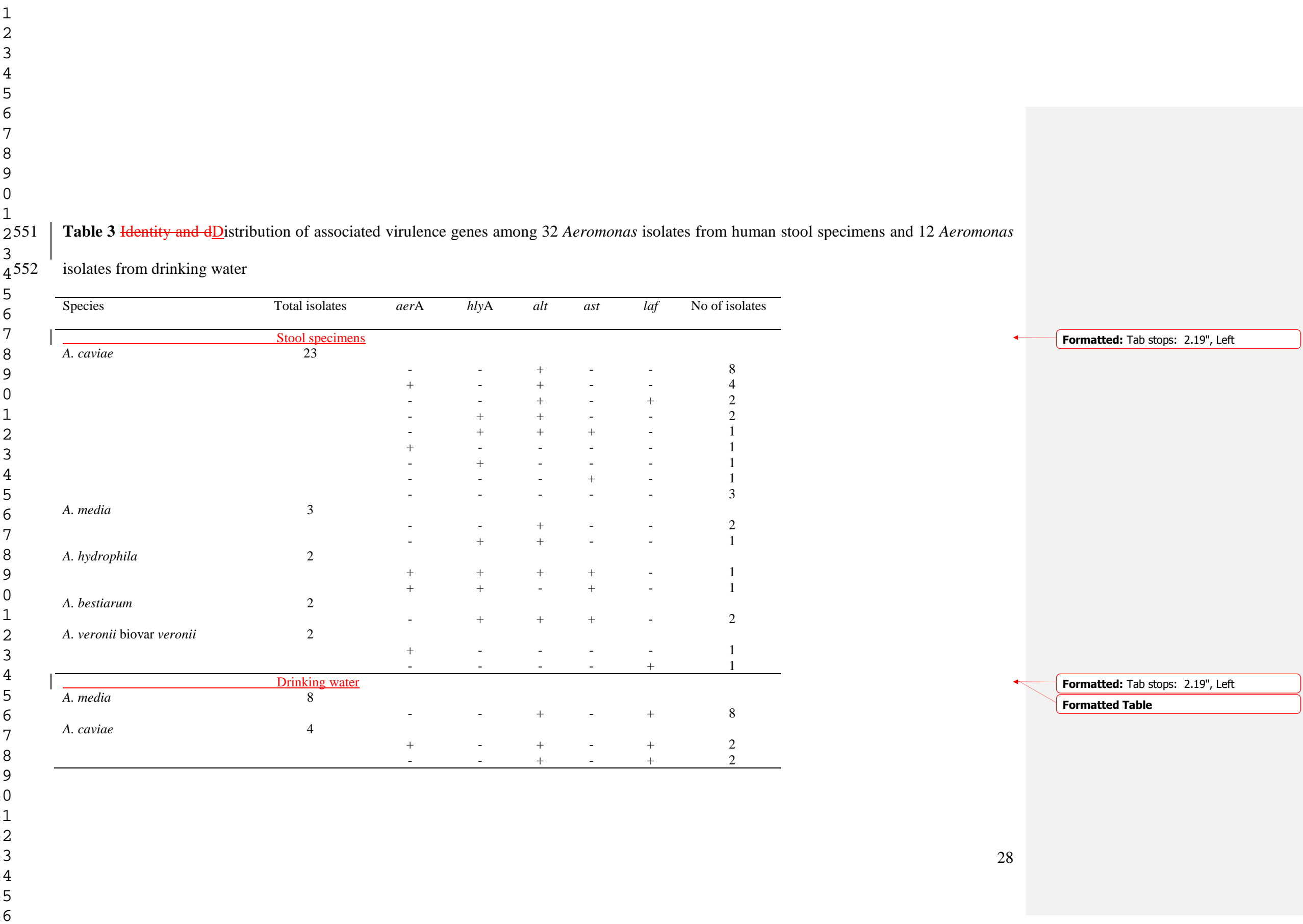


Fig. 1 Genetic similarity based on PFGE of Aeromonas strains from patients with diarrhea and drinking water. The horizontal upper bar represents genetic similarity (\%). Letters together strain number represent: $\mathrm{W}$, isolates from water samples and $\mathrm{H}$, isolates from clinical stools

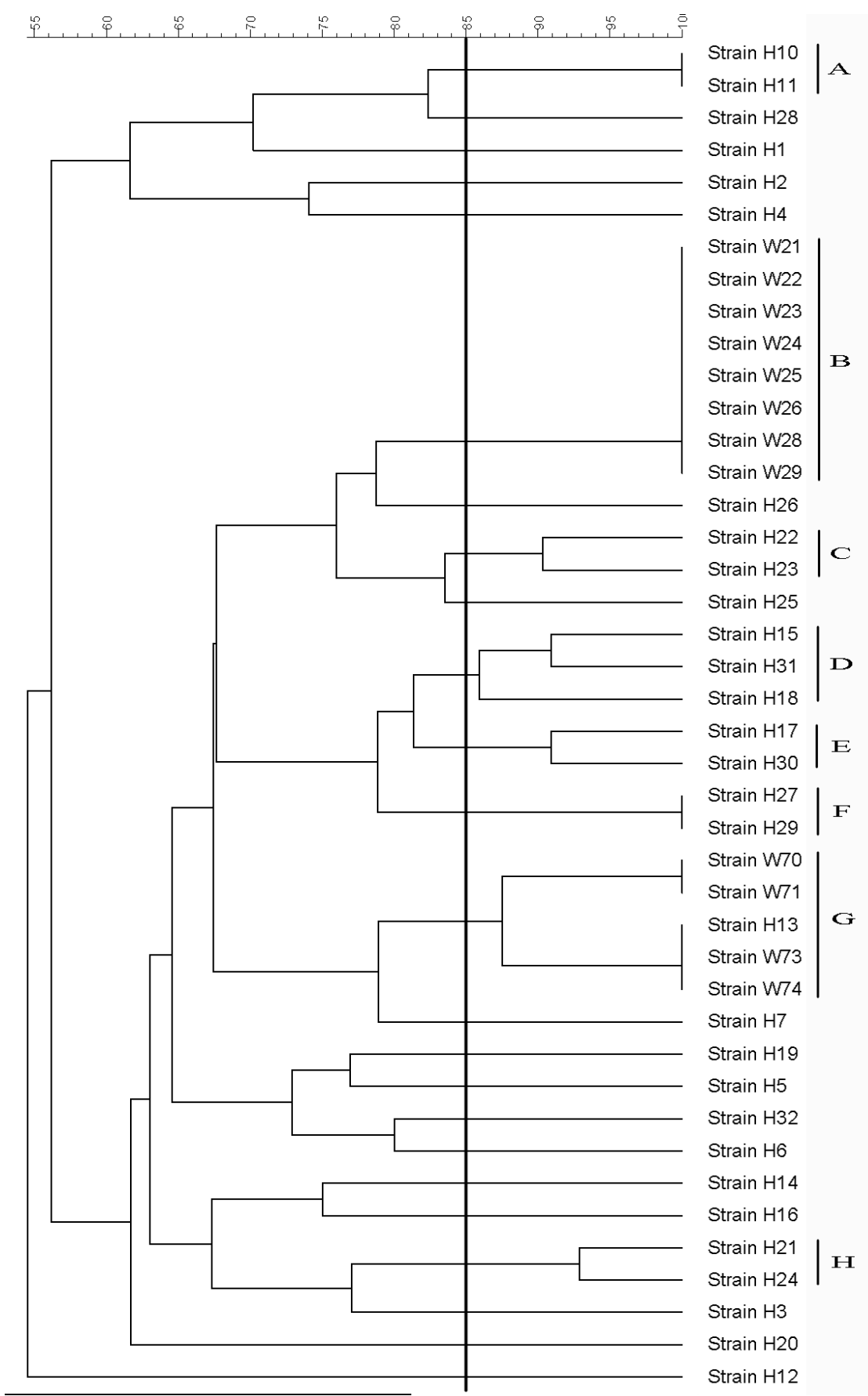

